Nadwa : Jurnal Pendidikan Islam

Vol. 14, No.1 (2020)

Accredited by Ristekdikti based on Decree No. 51/E/KPT/2017

DOI: 10.21580/nw.2020.14.1.6118

\title{
The Effect of Academic Background and Religious Orientation to Religious Fundamentalism among University Students
}

\section{Fihris}

Education Faculty of Education and Teacher Training

UIN Walisongo Semarang

fihris2013@gmail.com

\begin{abstract}
This paper discusses influence of the religious orientation and educational background of students to fundamentalism. This study involved 291 students of the UIN Walisongo and Diponegoro University (UNDIP). Data were collected using a Likert scale questionnaire and analyzed by multiple regression. The results showed that religious orientation significantly affected student religious fundamentalism with value of $f=17.523$. On the other hand, educational background does not significantly affect student religious fundamentalism with a value of $f=2.430$. Likewise, the interaction of religious orientation and educational background did not significantly affect student religious fundamentalism with a value of $\mathrm{f}=10.010$.

Keywords : Educational Background, Religious Fundamentalism, Religious orientation
\end{abstract}

\begin{abstract}
Abstrak
Penelitian ini membahas pengaruh orientasi agama dan latar belakang pendidikan mahasiswa terhadap fundamentalisme agama. Penelitian ini melibatkan 291 mahasiswa Universitas Islam Negeri (UIN) Walisongo dan Universitas Diponegoro (UNDIP). Data dikumpulkan dengan menggunakan kuesioner skala likert dan dianalisis dengan regresi ganda. Hasil penelitian menunjukkan bahwa orientasi keagamaan signifikan mempengaruhi fundamentalisme agama pada mahasiswa dengan nilai $f=17,523$. Sebaliknya latar belakang pendidikan tidak signifikan mempengaruhi fundamentalisme agama pada mahasiswa dengan nilai $\mathrm{f}=2,430$. Demikian juga interaksi orientasi keagamanan dan latar belakang pendidikan tidak signifikan mempengaruhi fundamentalisme agama pada mahasiswa dengan nilai $\mathrm{f}=$ 10,010 .
\end{abstract}

Keywords : Latar belakang pendidikan, agama, fundamentalisme 


\section{.Background}

The fundamentalist movements have spread worldwide including Indonesia. In 2018, a survey conducted by M. Dja'far showed that intolerance and radicalism had developed in schools and colleges. 1 Statistical data said that of the student population $(1,859)$ surveyed $51.1 \%$ had intolerant thoughts towards minority groups such as Ahmadiyah and Shia, $34.3 \%$ being intolerant to other religious groups, $58.5 \%$ had a radical view, and $48.95 \%$ of the students stated that religious education influenced them.2 This was confirmed by the Head of the State Intelligence Agency stating that $39 \%$ of students had been exposed to radical teachings. 3

The vigilance of fundamentalism was increasing, especially in Higher Education, for reasons. First, students were agents of social change; 4 they have pivotal roles in changing and developing society. Second, students were psychologically at the level of late adolescents, which was an important phase in shaping their religious identity.5 Third, students were a group of welleducated people who were expected to have critical and logic

1 Alamsyah M. Dja'far, Intoleransi Kaum Pelajar, http:// www. wahidinstitute. org/ wi-id/ indeks- opini/ 280- intoleransi-kaum-pelajar. html,

2 Terry Muthahhari, "Survei UIN Jakarta: Intoleransi Tumbuh di Banyak Sekolah dan Kampus", accessed on 8 November 2018, https://tirto.id/surveiuin-jakarta-intoleransi-tumbuh-di-banyak-sekolah-dan-kampus-czQL.

3Budi Gunawan, Kepala BIN: 39\% Mahasiswa Terpapar Ajaran Radikal, Suara Pembaharuan, 29 April 2018, http: //sp. beritasatu.com/ home/kepalabin-39-mahasiswa-terpapar-ajaran-radikal/123866, accessed on 8 November 2018.

4 Choirul Anwar, Islam dan Tantangan Kemanusiaan Abad XXI, (Yogjakarta, Pustaka Pelajar, 2000), p. 59.

5 W. Santrock, Adolescence, Mc Graw-Hill Book, New York, p. 5. 
thinking so that they had a strong stance when it comes to religion. 6

The spread of religious fundamentalism in higher education was allegedly caused by the students' educational background and religious orientation or religious attitude. 7 This hypothesis would be examined in this paper.

\section{Religious Fundamentalism.}

The term fundamentalism was usually related to "violence". This stereotype had been echoed by the West for centuries8 with various pejorative labels such as "fundamentalist", "militant", "radical", "terrorist", "modernist", "liberalist", "secularist", and so on.9 On the other hand, scholars described and analyze the movement as religious fundamentalism; the counterpoint to modernism and secularism. 10

6 Bahari, "Fundamentalisme agama Mahasiswa (Studi tentang Pengaruh Kepribadian, Keterlibatan Organisasi, Hasil Belajar Pendidikan Agama, dan Lingkungan Pendidikan terhadap Toleransi Mahasiswa Berbeda Agama pada 7 Perguruan Tinggi Umum Negeri)”,p. 10.

7 Syamsul Bahri, Islam dan Wacana Radikalisme Agama Kontemporer, Dinamika, Vol 3, No. 1, Januari 2014, https:// s3. Amazona ws.com/ academia. edu.documents/ 48848593/ Islam_dan_ Wacana_ Syamsul _Bakri_1.pdf? response-content- disposition $=$ inline $\% 3 \mathrm{~B} \%$ 20filename $\% 3$ DIslam_dan_Wacana_Syamsul_Bakri_Islam_dan. pdf\&X-AmzAlgorithm=, accessed on 17 October 2019.

8 Muhammad Harfin Zuhdi, Fundamentalisme Dan Upaya Deradikalisasi Pemahaman AL-Qur'an Dan Hadist, RELIGIA Vol. 13, No. 1, April 2010, p. 81.

9 al-Makasary Ridwan, Mengkaji Fundamentalisme IslamSebagai SuatuGerakan Sosial, see www.interseksi.org.

10 Marty Martin, and Appleby Scott, quoted by Bassam Tibbi, Ancaman Fundamentalisme Rajutan Islam Politik dan Kekacauan Dunia Baru, (Yogyakarta: Tiara Wacana, 2000), p. 3. 


\section{2 | Fihris}

This movement emerged in Christianity and the term refered to the movement that occurred in America in the late decades of the 19th and early 20th century. Unlike in the context of Islam, the first fundamentalism movement was not a religious phenomenon but rather a social one in the form of religion. This movement always points up to four things; tajdid movement, reaction to modernists, reaction to westernization, and belief in Islam as an alternative ideology. 11

Pyszczynski, Solomon, and Greenberg (2003) state that fundamentalism was a religious ideology that contained the absolute truth of life, which makes individuals psychologically benefit from the religion. Herriot (2007) defined religious fundamentalism as a pattern of militancy (though not always radical) of a group of people who considered themselves as the true adherents who prevented the decadence of religious identity and fortify the boundaries of their religious community. Moaddel and Karabenick (2008) state that fundamentalism was a unique set of religious beliefs and attitudes, including adherence to religious norms, ideologies of universality and eternal principles, and the validity of claims for human happiness. 12

Fundamentalism had several characteristics. First, scripturalism; a literal belief in the scriptures as the word of God which were considered being free of error. Second, the rejection

11 Ribut Karyono, Fundamentalisme Dalam Kristen-Islam, p. 11, Baidi Bukhori, "Toleransi Umat terhadap Kristiani Ditinjau dari Fundamentalisme Agama dan Kontrol Diri; Studi pada Jamaah Majelis Taklim di Kota Semarang", p. 32, Ricard T. Antoun, Memahami Fundamentalisme; Gerakan Islam dan Yahudi, (Surabaya: Altamira Press, 2003),p. 24.; Hassan Hanafi, Dialog Agama dan Revolusi I, (trans.) "Religious Dialogue \& Revolution", (Jakarta: Pustaka Firdaus, 1994), p. 121.

12 Baidi Bukhori, "Toleransi Umat terhadap Kristiani Ditinjau dari Fundamentalisme Agama dan Kontrol Diri; Studi pada Jamaah Majelis Taklim Di Kota Semarang”, p. 32. 
of hermeneutics. In the fundamentalism view, the text of The Qur'an must be taken literally as it reads. In this context, reason was not being able to provide a proper interpretation to the text, even to the Qur'anic texts that contradicted each other. Third, the rejection of pluralism and relativism which were considered to undermine the sanctity of the text. Fourth, the rejection of historical and sociological developments which were considered to bring humans further and further away from the literal doctrine of the scriptures. 13

In general, the factors of the fundamentalism movement were as follows; (1) Social Politics, (2) Religious Emotions, (3) Culture, (4) Government Policies. 14

\section{Educational Background}

Educational background here meant the educational environment of students before pursuing Higher Education. Sertain (American psychologist) explains that the word environment covered all the conditions in this world that in certain ways affect our behavior, growth, development or processes. 15 As in the hadith narrated by Bukhari16:

$$
\text { ما من مولود يولد علي الفطرة فا بواه يهو د ا نها او ينصر انه او يمجسا نها }
$$

This hadith confirmed that individual development was not only influenced by genetic, but also environmental factors.

13 Azyumardi Azra, "Fenomena Fundamentalisme dalam Islam," in Ulumul Qur'an No. 3, Vol. IV, year 1993, p. 18-19,

14 Syamsul Bahri, Islam dan Wacana Radikalisme Agama Kontemporer, Dinika, Vol 3, No. 1, Januari 2014,..

15 M. Ngalim Purwanto, Psikologi Pendidikan, Remaja Rosdakarya, Bandung, 2014, p. 28

16 Abu Abdullah bin Ismail al-Bukhari, (Jakarta, almahira, 2012), hadith no. 609 
Environment could shape someone's personality, character, and habits.

Type of education was divided into 2 (two), namely: first, the homogeneous educational environment was also called monocultural environment which tended to have one same culture within the school/education environment in terms of social status, religion, or ethnicity. Homogeneous (mono-cultural) education also tended to disregard differences and plurality, thereby blocking critical and creative personal growth.17 This was reinforced by the opinion of Calvin S. Hall, Gardner Lindzey, who asserted "a homogineous or undifferentiated is one in which all the facts are equally influential upon the person. In such an environment the person would have perfect freedom of movement since there would be no barriers to impede him or her". 18

Second, heterogeneous educational environment was a learning environment in which in some aspects was a tendency for diversity, or even it was a diverse environment. Heterogeneous educational environment creates open-minded students having willingness to understand and appreciate the existing diversity. 19 Heterogeneous education environment was also called multicultural education, namely education that involves more than one culture in terms of nationality, language, ethnicity and others. According to Tilaar, multiculturalism education offered an alternative through the application of education strategies and concepts based on the diversity in society, especially those of students, such as ethnic, culture,

17 Aris Saefulloh, Membaca Paradigma Pendidikan dalam bingkai Multikulturalisme, (Purwokerto: Insania, 2009),p. 14.

18 Calvin S. Hall \& Gardner Lindzey, The Theories of Personality, (USA, John Wiley \& Sons, 1978), 392.

19 Anwar Effendi, Sekolah sebagai Tempat Persamaan Nilai Multikulturalisme, (Jakarta: Insani, 2008), p.5 
language, religion, skin color, social status, gender, age, and race. 20

\section{Religious Orientation}

Religious orientation (religiosity) according to Allport \& Ross (1967) was the extent to which a person lives out his/her religious beliefs, namely the way a person realizes and practices his/her religious beliefs. This was related to the role or function of religion on one's life that becomes the motive underlying other motives. Religiosity can be simply said that religion is seen only as a means to fulfill one's personal life. 21

According to Batson and Ventis, religious orientation was a way in which a person runs or uses his religious beliefs and values. Allport and Ross (1967) explain that religious expression was divided into 2, intrinsic and extrinsic. Intrinsic orientation meant a comprehensive commitment to religious beliefs embraced and how a religion impacts on every aspect of one's life. On the other hand, extrinsic religious orientation refered to the behavior of individuals who use religion as power through participation in group. In addition, extrinsic religious orientation was also indicated through behavior that uses religion as protection, escape, social status, participation in religious groups, and ego defense. 22

20 H.A.R. Tilaar, Beberapa Agenda Reformasi Pendidikan Nasional, (Magelang: Tera Indonesia, 1999),p 129.

${ }_{21}$ Gordon W. Allport and J. Michael Ross, Personal Religious Orientation and Prejudice, (Harvard University: Journal of Personality and Social Psychology, 1967), Vol. 5, No. 4, p. 432-443, Jalaludin, Psikologi Agama, Memahami Prilaku Keberagamaan dengan Mengaplikasikan PrinsipPrinsip Psikologi, Revised Edition, (Jakarta: PT. RajaGrafindo Persada, 2005), p. 253.

22 Wibisono, S., \& Taufik, M. Orientasi Keberagamaan Ekstrinsik dan Fundamentalisme Agama pada Mahasiswa Muslim: Analisis dengan Model 
The aspects of intrinsic religious orientation are: 1) Bringing religious values closer to life; 2) Doing activities in worship places for religious purposes; 3 ) Personal prayers for religious purposes. The aspects of extrinsic religious orientation are: 1) Separation of religion from educational values; 2) Placing religion as social support; 3) Using religion through prayers for self-comfort. 23

Slightly different from Allport and Ross, Panikkar classified diversity into three, namely extrinsic, intrinsic, and parallelism.24 While Komarudin Hidayat mentioned five typologies of religious attitudes, namely exclusivism, inclusivism, pluralism, eclectivism, and universalism.25

The intrinsic aspects of religious orientation were: 1) Bringing religious values closer to life; 2) Conducting activities religious places for religious purposes; 3) Personal prayers for religious purposes. The extrinsic aspects of religious orientation were: 1) Separation of religion from educational values; 2) Placing religion for social support; 3) Utilizing religion through prayer for self-comfort.26

Rasch, Jurnal Psikologi Sosial, UII Yogjakarta, 2017, Vol. 15, No. 01, p. 1-1. Edi Susanto, Pluralitas Agama: Meretas Toleransi Berbasis Multikulturalisme Pendidikan Agama, Tadris: Jurnal Pendidikan Islam, Volume 1, No. 1, 2006.

${ }_{23}$ Rini Risnawita Suminta, "Hubungan Antara Tipe Kepribadian Dengan Orientasi Religiusitas", Fikrah: Jurnal Ilmu Aqidah dan Studi Keberagamaan Volume 4 Nomor 2, (2016), 218

24Adeng Muchtar Ghazali, “Tipologi Sikap Beragama”, accessed on 26 February 2017, https://amgy. wordpress.com /2008/03/29/tipologi-sikapberagama.

25 Edi Susanto, "Pluralitas Agama :Meretas Toleransi Berbasis Multikulturalisme Pendidikan Agama”, Tadris: Jurnal Pendidikan Islam (2006), 1.

26Rini Risnawita Suminta, "Hubungan Antara Tipe Kepribadian Dengan Orientasi Religiusitas", Fikrah: Jurnal Ilmu Aqidah dan Studi Keberagamaan Volume 4 Nomor 2, (2016), 218, accessed on 21 February 2018, 


\section{Result of Research Description.}

Before hypothesis testing, it would first test the normality of the data. The data used in this test were religious orientation (X1), educational environment (X2), and religious fundamentalism (Y) using Kolmogorov Smirnov with the following results:

Normality Test Results SPSS 16.0

One-Sample Kolmogorov-Smirnov Test

\begin{tabular}{|lll|}
\multicolumn{1}{c|}{} & \multicolumn{1}{c|}{$\begin{array}{c}\text { Unstandardized } \\
\text { Predicted Value }\end{array}$} \\
\hline $\mathrm{N}$ & & 291 \\
\hline Normal Parameters ${ }^{\mathrm{a}, \mathrm{b}}$ & Mean & 42.9896907 \\
\cline { 2 - 3 } & Std. Deviation & 1.17565188 \\
\hline Most Extreme Differences & Absolute & .052 \\
\cline { 2 - 3 } & Positive & .047 \\
\cline { 2 - 3 } & Negative & -.052 \\
\hline Test Statistic & & .052 \\
\hline Asymp. Sig. (2-tailed) & & $.056^{\mathrm{c}}$ \\
\hline
\end{tabular}
a. Test distribution is Normal.
b. Calculated from data.
c. Lilliefors Significance Correction.

The normality testing criteria was:

If Sig. $>\mathbf{0 , 0 5}=$ normally distributed data

Based on SPSS output, it was known that the Asymp value. Sig was 0.056 greater than 0.05 , so it could be concluded that the data were normally distributed.

https://media.neliti.com/media /publications/61278-ID-hubungan-antara-tipekepribadian-dengan.pdf/. 


\section{Simple Regression Test of Variable $X 1$ against $Y$}

Based on the data obtained, the next step was to look for averages and standard deviations on variable X1 (religious orientation) and $\mathrm{Y}$ variable (religious fundamentalism) using the SPSS program, and produced the following output:

\begin{tabular}{lr|r|r|c|c}
\hline \multicolumn{6}{c}{ ANOVA $^{\mathbf{a}}$} \\
\hline Model & $\begin{array}{c}\text { Sum of } \\
\text { Squares }\end{array}$ & Df & $\begin{array}{c}\text { Mean } \\
\text { Square }\end{array}$ & F & Sig. \\
\hline Regression & 352.548 & 1 & 352.548 & 17.523 & $.000^{\mathrm{b}}$ \\
\hline Residual & 5814.421 & 28 & 20.119 & & \\
& & 9 & & & \\
\hline Total & 6166.969 & 29 & & & \\
& & 0 & & & \\
\hline
\end{tabular}
a. Dependent Variable: Fundamentalism
b. Predictors: (Constant), Religious_Orientation

Based on the above results $\mathrm{f}$ arithmetic $=17.523 \mathrm{f}$ table of 3.87 then $\mathrm{f}$ arithmetic $>\mathrm{f}$ table was thus declared significant, and the significance value was 0.000 with a significance level of 0.05 , then $0.000<0.05$ so that Ho: was rejected, meaning that both (X1 and $\mathrm{Y}$ ) there was a correlation or relationship.

\section{Simple Regression Test of Variable X2 against Y}

Based on the data, the next step was to look for averages and standard deviations on the $\mathrm{X} 2$ variable (educational environment) and $\mathrm{Y}$ variable (fundamentalism) using the SPSS program, and produced the following output: 


\begin{tabular}{|c|c|c|c|c|c|}
\hline \multicolumn{6}{|c|}{ ANOVA $^{a}$} \\
\hline $\begin{array}{l}\text { Sum of } \\
\text { Squares }\end{array}$ & $\mathrm{df}$ & $\begin{array}{l}\text { Mean } \\
\text { Square }\end{array}$ & $\mathrm{F}$ & Sig. & \\
\hline Regression & 51.429 & 1 & 51.429 & 2.430 & $\begin{array}{r}.12 \\
0^{\mathrm{b}}\end{array}$ \\
\hline Residual & $\begin{array}{r}6115.5 \\
40\end{array}$ & 289 & 21.161 & & \\
\hline Total & $\begin{array}{r}6166.9 \\
69\end{array}$ & 290 & & & \\
\hline
\end{tabular}

a. Dependent Variable: Fundamentalism

b. Predictors: (Constant), Educational_Environment

Based on the results of $\mathrm{f}$ arithmetic $=2,430 \mathrm{f}$ table of 3.87 then $\mathrm{f}$ arithmetic $<\mathrm{f}$ table was thus declared insignificant, and a significance value of 0.120 with a significance level of 0.05 , then $0.120>0.05$ so that Ho: was accepted, meaning that both (X2 and Y ) there was no correlation or relationship.

\section{Multiple Regression Test of Variables X1, X2 against Y}

Multiple linear regression test was used to find out how much influence or contribution of variable X1 (religious orientation) variable X2 (educational environment) to variable $\mathrm{Y}$ (fundamentalism), the value of multiple regression coefficients was as follows: 
ANOVA $^{\mathrm{a}}$

\begin{tabular}{|c|c|c|c|c|c|}
\hline Model & $\begin{array}{l}\text { Sum of } \\
\text { Squares }\end{array}$ & Df & $\begin{array}{l}\text { Mean } \\
\text { Square }\end{array}$ & $\mathrm{F}$ & Sig. \\
\hline Regression & 400.826 & 2 & 200.413 & 10.010 & $.000^{\mathrm{b}}$ \\
\hline Residual & $\begin{array}{r}5766.14 \\
3\end{array}$ & $\begin{array}{r}28 \\
8\end{array}$ & 20.021 & & \\
\hline Total & $\begin{array}{r}6166.96 \\
9 \\
\end{array}$ & $\begin{array}{r}29 \\
0 \\
\end{array}$ & & & \\
\hline
\end{tabular}

a. Dependent Variable: Fundamentalism

b. Predictors: (Constant), Educational_Environment, Religious_Orientation

Based on the ANOVA table, the $\mathrm{f}$ arithmetic $=10,010 \mathrm{f}$ table of 3,027 for a significance level of 5\%, then $f$ arithmetic $>f$ table was thus declared significant, based on a significance value of 0,000 and a significance level of 0.05 . Then $0,000<0.05$. So Ho: REJECTED, meaning that all three variables (X1, X2 and Y) had a correlation or relationship.

\section{Analysis and Discussion}

The results of the data analysis presented previously support the hypothesis of the main effect supporting diversity, but did not support the hypothesis of the main effect of educational background, and the effect of interactions between or across sustainability and educational background. As expected, factors of religious orientation and educational background possessed by students had influenced religious fundamentalism towards other groups. But the educational background and the interaction between the two did not affect religious fundamentalism in college students in Semarang. Thus, differences in one factor across other factors were consistently reflected in differences in religious fundamentalism. 
The government as a policy maker and education practitioners must revitalize the courses of citizenship education, and religion. By understanding the citizenship, students were directed to foster a spirit of nationality and responsible citizenship and anti-radicalism. In addition, through religious education students would be directed to strengthen the perspective of national diversity and be oriented towards strengthening intellectual attitudes about religious diversity and intra-religious and inter-religious tolerance as well as between religious communities and the state. Apart from aspects of the curriculum that should be taught in the campus environment, encouraging efforts were needed so that the organizations formed in higher education were more effectively attended by students. From the scope of this organization students would truly be trained to live in a heterogeneous society, had a diversity of ways to interact, had a variety of ways to interact, have a variety of ideas of creativity and views.

This would be more conducive, if supported by mass media and social media that intensively socialize the values of pluralism that was anti-radicalism. Through this social media support, it was hoped that synergistically it would support the antifundamentalism movement that leads to acts of intolerance.

\section{Conclusion}

The Factors of religious orientation and educational background possessed by students had influenced religious fundamentalism towards other groups. But the educational background and the interaction between the two did not affect religious fundamentalism in college students in Semarang. Thus, differences in one factor across other factors were consistently reflected in differences in religious fundamentalism. 


\section{Bibliography}

Abdullah, Subhan et.al, Ensiklopedia Hadist 2: Shahih Bukhari 2/ Abu Abdullah bin Ismail al-Bukhari, Jakarta, almahira, 2012, hadist ke 609.

Allport, Gordon W. and J. Michael Ross, Personal Religious Orientation and Prejudice, (Harvard University: Journal of Personality and Social Psychology, 1967), Vol. 5, No. 4, 432-443.

Anwar, Choirul, Islam dan Tantangan Kemanusiaan Abad XXI, Pustaka Pelajar, Yogjakarta, 2000.

Azra, Azyumardi, "Fenomena Fundamentalisme dalam Islam," dalam Ulumul Qur'an No. 3, Vol. IV, tahun 1993.

Azra, Azyumardi, Pergolakan Politik Islam, Jakarta: Paramadina, 1996.

Bahari, "Fundamentalisme agama Mahasiswa (Studi tentang Pengaruh Kepribadian, Keterlibatan Organisasi, Hasil Belajar Pendidikan Agama, dan Lingkungan Pendidikan terhadap Toleransi Mahasiswa Berbeda Agama pada 7 Perguruan Tinggi Umum Negeri)", Jakarta, Badan Litbang dan Diklat Puslitbang Kehidupan Keberagamaan, 2010.

Bahri, Syamsul, Islam dan Wacana Radikalisme Agama Kontemporer, Dinika, Vol 3, No. 1, Januari 2014,

Bahri, Syamsul, Islam dan Wacana Radikalisme Agama Kontemporer, _Dinamika, Vol 3, No. 1, Januari 2014, https:// s3. Amazona ws.com/academia. edu.documents/ 48848593/ Islam_dan_ Wacana_ Syamsul _Bakri_1.pdf? responsecontent- disposition $=$ inline $\% 3 \mathrm{~B} \%$ 20filename $\% 3$ DIslam_dan_Wacana_Syamsul_Bakri_Islam_dan.pdf\&XAmz- Algorithm=

Bukhori, Baidi, Toleransi Umat terhadap Kristiani Ditinjau dari Fundamentalisme Agama dan Kontrol Diri (Studi pada 
Jamaah Majelis Taklim Di Kota Semarang), Penelitian Individual yang didanai oleh Anggaran DIPA IAIN Walisongo Semarang tahun 2012.

Effendi, Anwar, Sekolah sebagai Tempat Persamaan Nilai Multikulturalisme, Insani, Jakarta, 2008.

Hall, Calvin S. \& Gardner Lindzey, The Theories of Personality, USA, John Wiley \& Sons, 1978.

Harfin, Muhammad Zuhdi, Fundamentalisme dan Upaya Deradikalisasi Pemahaman Al-Qur'an dan Hadist, Religia, Vol. 13, No. 1, April 2010.

Hassan Hanafi, Dialog Agama dan Revolusi I, (terj.) dari "Religious Dialogue \& Revolution", Jakarta: Pustaka Firdaus, 1994.

H.A.R. Tilaar, Beberapa Agenda Reformasi Pendidikan Nasional, Magelang: Tera Indonesia, 1999.

Jalaludin, Psikologi Agama, Memahami Prilaku Keberagamaan dengan Mengaplikasikan Prinsip-Prinsip Psikologi, Edisi Revisi, Jakarta: PT. Raja Grafindo Persada, 2005.

Karyono, Ribut, Fundamentalisme Dalam Kristen-Islam, Kalika bekerjasama dengan Yayasan Adikarya IKAPI dan Ford Foundation, Yogjakarta, 2003.

Susanto, Edi, Pluralitas Agama: Meretas Toleransi Berbasis Multikulturalisme Pendidikan Agama, Tadris: Jurnal Pendidikan Islam, Volume 1, Nomor 1, 2006.

al-Makasary Ridwan, Mengkaji Fundamentalisme Islam Sebagai Suatu Gerakan Sosial, dalam www.interseksi.org.

Marty Martin, dan Appleby Scott dikutip dalam Bassam Tibbi, Ancaman Fundamentalisme Rajutan Islam Politik dan Kekacauan Dunia Baru, Yogyakarta: Tiara Wacana, 2000. Muchtar, Adeng Ghazali, "Tipologi Sikap Beragama", accessed on 26 February 2017, https://amgy. wordpress.com /2008/03/29/tipologi-sikap-beragama. 
M. Dja'far, Alamsyah, Intoleransi Kaum Pelajar, http:// www. wahidinstitute. org/ wi-id/ indeks- opini/ 280- intoleransikaum-pelajar. html,

Terry Muthahhari, "Survei UIN Jakarta: Intoleransi Tumbuh di Banyak Sekolah dan Kampus", diakses 8 Nopember 2018, https://tirto.id/survei-uin-jakarta-intoleransi-tumbuh-dibanyak-sekolah-dan-kampus-czQL.

Gunawan, Budi, Kepala BIN: 39\% Mahasiswa Terpapar Ajaran Radikal, Suara Pembaharuan, 29 April 2018, http: //sp. beritasatu.com/ home/kepala-bin-39-mahasiswa-terpaparajaran-radikal/123866, diakses 8 Nopember 2018.

Marty Martin, dan Appleby Scott dikutip dalam Bassam Tibbi, Ancaman Fundamentalisme Rajutan Islam Politik dan Kekacauan Dunia Baru, Yogyakarta: Tiara Wacana, 2000

Ricard T. Antoun, Memahami Fundamentalisme; Gerakan Islam dan Yahudi, Surabaya: Altamira Press, 2003.

Purwanto, M. Ngalim Psikologi Pendidikan, Remaja Rosdakarya, Bandung, 2014.

Umi Hijriyah, et.al., "Pengaruh Lingkungan Pendidikan dan Tipe Kepribadian terhadap Konflik Sosial Kelompok Antar Agama (Studi Survey pada Lingkungan Pendidikan di Tingkat Menengah Atas di Kabupaten Lamsel)", Puslit, IAIN Raden Intan Lampung, 2013.

Saefulloh, Aris, Membaca Paradigma Pendidikan dalam bingkai Multikulturalisme, Purwokerto: Insania, 2009.

Wibisono, S., \& Taufik, M. Orientasi Keberagamaan Ekstrinsik dan Fundamentalisme Agama pada Mahasiswa Muslim: Analisis dengan Model Rasch, Jurnal Psikologi Sosial, UII Yogjakarta, 2017, Vol. 15, No. 01 